\title{
COMPOSITION OF STRAINS BRADYRHIZOBIUM JAPONICUM AND ITS USE FOR SOYBEAN INOCULATION
}

\author{
D. V. Krutylo \\ Institute of Agricultural Microbiology and Agroindustrial Manufacture, NAAS \\ 97, Shevchenka str., Chernihiv, 14027, Ukraine; e-mail: krutilod@mail.ru
}

In the vegetation experiment conditions it was established that the greatest effect of soybean bacterization can be obtained by two strains of nodule bacteria with slow (Bradyrhizobium japonicum 46) and intensive (B. japonicum KB11) growth rates when these strains used in inoculum in the ratio $1: 1$ (binary composition). In compared to the mono-inoculation the combined use of these strains contributed the formation of balanced symbiotic system, increase the level of molecular nitrogen fixation, content of chlorophyll in the biomass leaves and above ground mass of different soybean plants varieties on 7.8-19.6\%. In a field experiment inoculation of soybean seeds with a composition of B. japonicum strains to increase the soybean yields by 11.1-13.7\% compared to the mono-inoculation.

Key words: Bradyrhizobium japonicum, binary composition of strains, competitiveness, inoculation, yield, soybean.

An important reserve to increase productivity of legumes is the use of rhizobia, which functions in plant-microbial interaction are diverse: a molecular nitrogen fixation, improved nutrition of plants, synthesis of biologically active substances, increase of plant resistance to the action of pathogens and abiotic stresses $[1 ; 2]$.

It is known that in regions of intensive soybean cultivation using biological preparations based on rhizobia, soils form different population of these microorganisms in terms of density. Local populations are considered as a source of economically valuable strains, on the other hand, they can act as competitors of bioagents of microbial preparations in soil [2-4].

During the study of populations of soybean microsymbionts in soils of Ukraine, among their representatives we found strains with increased growth rate, which conventionally called "strains of intense growth". Method of analytical selection gave new highly effective strains of rhizobia from soybean with slow (Bradyrhizobium japonicum 46$)$ and intensive (B. japonicum KB11) growth. It has been established that the strains of intense growth are characterized by increased saprophytic competence (survival in soil) compared with slowly growing rhizobia [5]. Property for better survival in soil characteristic for rhizobia with intense growth can be used in practice to develop new microbial preparations with a wide range of performance.

It should be noted that the list of biological preparations for the plant production over the past decade have expanded to include preparations based on microorganisms of various functional groups and preparations of binary action, obtained as a result of a combination of several microorganisms [6]. Today, it has been experimentally proved the significant stimulating effect of the mixed cultures of microorganisms on the growth and development of plants. Compared with pure cultures of diazotrophs, consortia of microorganisms are characterized by increased efficiency and stability of action on plants, which makes the prospects of their use in agricultural practice $[7 ; 8]$.

The possibility of using biological preparations of several strains of rhizobia belonging to the same species has been poorly studied. For example, A. I. Chunderova et al. [9] in field experiments with peas show that multistrain (two to three strains) inoculation of peas gives higher and more stable yields than monostrain. The authors made a conclusion about the prospects of multistrain preparations when growing peas.

We believe that the use of some highly efficient strains of soybean rhizobia with different 
survival strategy in soil for biological preparations to inoculate soybean seeds can help to not only increase productivity of the culture, but also the formation of stable active population of specific rhizobia in soil.

Considering the above, the objective of our work was to study the effect of binary composition of the strains of soybean rhizobia with different rates of growth on soybean symbiotic performance of different varieties.

Materials and methods. The objects of the study were strains of soybean rhizobia with slow (B. japonicum 46) and intensive (B. japonicum KB11) growth, antisera to these strains, and soybean varieties Ustia and Omega Vinnytska.

In vegetation experiments, we studied the effect of binary composition of strains (B. japonicum $46+$ B. japonicum KB11) on the symbiotic parameters, growth, and development of soybean plants.

Cultures of rhizobia were grown separately in $250 \mathrm{~mL}$ flasks with legume medium on an orbital shaker at $180-200 \mathrm{rpm}$ at $+28 \ldots+30^{\circ} \mathrm{C}$ for 72 hours. The titre of bacteria was 2-4 $\times 10^{9} \mathrm{CFU} / \mathrm{mL}$. We studied different ratios of strains of B. japonicum 46 and B. japonicum KB11 in the inoculum $(1: 1,1: 2,2: 1,1: 3$, $3: 1,1: 4,4: 1)$. Bacterial load in case of pretreatment of seeds in all variants was 200 300 cells per 1 seed.

Experiments were conducted in the greenhouse in $2 \mathrm{~L}$ vessels. As the substrate, sodpodzolic soil ( $\mathrm{pH}_{\text {wat }}$. 5.5-5.9; humus content $1.0 \%$ that of easily hydrolyzed nitrogen (by $\mathrm{Ti}-$ urin and Kononova) - 55,0-60,0 mg; $\mathrm{P}_{2} \mathrm{O}_{5}-$ $150,0-160,0 \mathrm{mg}$ and $\mathrm{K}_{2} \mathrm{O}$ (by Kirsanov) $100,0-110,0 \mathrm{mg}$ per $1 \mathrm{~kg}$ of soil), in which no local soybean rhizobia were used. Soybean of two varieties was cultivated: Ustia and Omega Vinnytska. Frequency of experiment is fivefold. Humidity was maintained at $60 \%$ natural humidity.

Efficiency of legume-rhizobia symbiosis was assessed by the following parameters: content of dry matter content in the top, plant height, nodule-forming ability and activity of symbiotic nitrogen fixation. The content of photosynthetic pigments in leaves of plants was measured in the flowering stage by spectrophotometry [10].

The competitiveness of the studied strains (ratio of nodules formed by strain to the total number of studied nodules of each variant, expressed in per cent) was determined by GruberWidal agglutination method [11]. We used antisera, obtained to slowly growing strain $B . j a$ ponicum 46 and intensely growing strain $B$. japonicum KB11. To establish the serological identity of strains of soybean rhizobia, selected nodules were thoroughly washed with water. Each nodule was crushed in a penicillin vial with $1.2 \mathrm{~mL}$ of normal saline solution. The resulting homogenate was used as an antigen in agglutination with specific antisera. Forty-eight nodules were analysed from each variant. The following variants were used as the controls: normal saline solution + antigen (homogenate of nodules) and antiserum + antigen (pure culture of rhizobia against which the antiserum was obtained).

The effectiveness of combined use of two strains of soybean rhizobia with slow and intense growth was studied in the field at the zone of Polissia of Ukraine (experimental field of the Institute of Agricultural Microbiology and Agroindustrial Manufacture of the NAAS). The strains of B. japonicum and B. japonicum KB11 were used in ratio $1: 1$. Inoculation load was 200-300 cells per 1 seed. Soil - leached black soil with small population of soybean rhizobia. Frequency of experiment - fourfold. Area of accounting field $-6 \mathrm{~m}^{2}$. Placement of fields randomised. Soybean of Ustia variety was cultivated.

The activity of symbiotic nitrogen fixation was determined by acetylene ethylene method [12] on the gas chromatograph Chrom-4 with a flame ionization detector (column with $\beta-\beta^{\prime}-$ oxydipropionitrile). The temperature of the thermostat is $50{ }^{\circ} \mathrm{C}$. Gas rate: hydrogen $30 \mathrm{~mL} / \mathrm{min}$, nitrogen $-100 \mathrm{~mL} / \mathrm{min}$, air $500 \mathrm{~mL} / \mathrm{min}$.

Processing of data was performed by computer programs Microsoft Office Excel and Statistica 7.0

Results and discussion. Vegetation experiment with soybean of Ustia variety was performed on sod-podzolic soil without soybean rhizobia, therefore, nodules were not formed on the roots of plants in the control variant (without inoculation) (Table 1).

Inoculation of soybean seeds separately for strains of rhizobia with intense (B. japonicum KB11) and slow (B. japonicum 46) growth promoted formation of significant number of 
Table 1. Symbiotic parameters, growth and development of soybean of variety Ustia under the effect of inoculation with binary composition of strains B. japonicum, vegetation experiment

\begin{tabular}{|c|c|c|c|c|c|}
\hline Variants of experiment & $\begin{array}{c}\text { Plant } \\
\text { height, } \\
\mathrm{cm}\end{array}$ & $\begin{array}{l}\text { Dry top, } \\
\text { g/plant }\end{array}$ & $\begin{array}{c}\text { Number of } \\
\text { nodules, } \\
\text { U/plant }\end{array}$ & $\begin{array}{l}\text { Weigh of } \\
\text { nodules, } \\
\text { g/plant }\end{array}$ & $\begin{array}{l}\text { Activity of } \\
\text { symbiotic nitro- } \\
\text { gen fixation, } \\
\mu \mathrm{g} \text { of } \mathrm{N} \text { per plant } \\
\text { per hour }\end{array}$ \\
\hline Without inoculation (control) & 39.38 & 0.98 & 0 & 0 & 0 \\
\hline Inoculation with $B$. japonicum 46 & 45.26 & 1.29 & 13.22 & 0.25 & 11.18 \\
\hline $\begin{array}{l}\text { Inoculation with } \\
\text { B. japonicum KB11 }\end{array}$ & 44.17 & 1.23 & 7.61 & 0.18 & 9.42 \\
\hline $\begin{array}{l}\text { Inoculation with } B \text {. japonicum } 46 \\
+ \text { B. japonicum KB11 }(\mathbf{1}: \mathbf{1})\end{array}$ & 48.58 & 1.39 & 15.44 & 0.29 & 14.72 \\
\hline $\begin{array}{l}\text { Inoculation with } B \text {. japonicum } 46 \\
+ \text { B. japonicum KB11 (1 : 2) }\end{array}$ & 47.13 & 1.32 & 16.72 & 0.25 & 10.59 \\
\hline $\begin{array}{l}\text { Inoculation with } B . \text { japonicum } 46 \\
+ \text { B. japonicum } \mathrm{KB} 11(\mathbf{2}: \mathbf{1})\end{array}$ & 45.70 & 1.30 & 21.78 & 0.27 & 13.24 \\
\hline $\begin{array}{l}\text { Inoculation with } B \text {. japonicum } 46 \\
+ \text { B. japonicum KB11 (1: 3) }\end{array}$ & 44.12 & 1.33 & 16.00 & 0.29 & 11.92 \\
\hline $\begin{array}{l}\text { Inoculation with } B \text {. japonicum } 46 \\
+B \text {. japonicum KB11 (3: : })\end{array}$ & 42.24 & 1.36 & $\mathbf{1 7 . 0 0}$ & 0.29 & 12.21 \\
\hline $\begin{array}{l}\text { Inoculation with B. japonicum } 46 \\
+ \text { B. japonicum KB11 (1: 4) }\end{array}$ & 44.11 & 1.30 & 15.33 & 0.28 & 9.42 \\
\hline $\begin{array}{l}\text { Inoculation with B. japonicum } 46 \\
+ \text { B. japonicum KB11 (4: 1) }\end{array}$ & 41.81 & 1.37 & 10.44 & 0.28 & 14.86 \\
\hline $\mathrm{HIP}_{05}$ & 2.03 & 0.07 & 2.33 & 0.03 & 2.27 \\
\hline
\end{tabular}

Note. In this and subsequent tables, reliable rise regarding parameters with monoinoculation is in bold.

nodules ( 8 and 13 units / plant, respectively) with high nitrogenase activity $(9.42$ and $11.18 \mu \mathrm{g} N$ per plant per hour). A positive effect of the studied cultures on such parameters as plant height and their top has been noted.

Analysis of the obtained data showed that the combined use of two strains of soybean rhizobia with different rate of growth is more effective than monoinoculation. Thus, in most variants, regardless of the ratio of strains in the inoculum, the use of binary composition of B. japonicum $46+$ B. japonicum KB11 provided a significant increase in the number of nodules (1.2-2.9 times) and their weight (1.1-1.6 times) compared with monoinoculation. In addition, the combination of two strains gave a significant increase of the level of nitrogenase activity in the nodules (1.3-1.6 times).

Better than most parameters (height and top, weight of nodules and activity of symbiotic nitrogen fixation), was combined use of strains of B. japonicum 46 and B. japonicum KB11 in equal proportions $-1: 1$. Reliable gain of the top, weight of nodules and their nitrogenase activity has been also noted upon domination of slowly growing strain $B$. japonicum 46 in inoculum, when its proportion compared with intensely grown strain B. japonicum KB11 was $4: 1$. It should be noted that in case of absolute dominance of the strain with slow growth in nodules (monoinoculation with B. japonicum 46), these parameters were lower. That is, the interaction of the host plant with two active strains of soybean rhizobia forms more efficient symbiotic systems than the use of each strain separately. This fact can explain the synergistic effect of the studied microorganisms which functionally complement each other in binary composition.

Similar results were obtained in vegetation experiment with soybean of Omega Vinnytska variety. Concomitant use of slowly and intensely growing strains had a positive effect on symbiotic parameters, growth, and development of soybean plants (Table 2). 
Table 2. Symbiotic parameters, growth and development of soybean of variety Omega Vinnytska under the effect of inoculation with binary composition of strains B. japonicum, vegetation experiment

\begin{tabular}{|c|c|c|c|c|c|}
\hline Variants of experiment & $\begin{array}{c}\text { Plant } \\
\text { height, } \\
\mathrm{cm}\end{array}$ & $\begin{array}{l}\text { Dry top, } \\
\text { g/plant }\end{array}$ & $\begin{array}{c}\text { Number of } \\
\text { nodules, } \\
\text { U/plant }\end{array}$ & $\begin{array}{l}\text { Weigh of } \\
\text { nodules, } \\
\text { g/plant }\end{array}$ & $\begin{array}{c}\text { Activity of } \\
\text { symbiotic nitro- } \\
\text { gen fixation, } \\
\mu \mathrm{g} \text { of } \mathrm{N} \text { per plant } \\
\text { per hour }\end{array}$ \\
\hline Without inoculation (control) & 33.98 & 1.40 & 0 & 0 & 0 \\
\hline Inoculation with $B$. japonicum 46 & 43.21 & 2.06 & 21.50 & 0.38 & 13.83 \\
\hline $\begin{array}{l}\text { Inoculation with } \\
\text { B. japonicum KB11 }\end{array}$ & 43.07 & 2.02 & 21.33 & 0.38 & 13.24 \\
\hline $\begin{array}{l}\text { Inoculation with B. japonicum } 46 \\
+ \text { B. japonicum KB11 (1 : 1) }\end{array}$ & 47.89 & 2.24 & 25.00 & 0.42 & 25.60 \\
\hline $\begin{array}{l}\text { Inoculation with B. japonicum } 46 \\
+ \text { B. japonicum KB11 (1:2) }\end{array}$ & 44.99 & 2.11 & 20.61 & 0.38 & 12.07 \\
\hline $\begin{array}{l}\text { Inoculation with B. japonicum } 46 \\
+ \text { B. japonicum KB11 (2: 1) }\end{array}$ & 45.34 & 2.17 & 20.89 & 0.40 & 19.42 \\
\hline $\begin{array}{l}\text { Inoculation with } B \text {. japonicum } 46 \\
+ \text { B. japonicum } \mathrm{KB} 11(\mathbf{1}: \mathbf{3})\end{array}$ & 45.57 & 2.06 & 20.94 & 0.39 & 14.72 \\
\hline $\begin{array}{l}\text { Inoculation with } B \text {. japonicum } 46 \\
+ \text { B. japonicum } \mathrm{KB} 11(\mathbf{3}: \mathbf{1})\end{array}$ & 47.35 & 2.13 & 18.94 & 0.40 & 18.54 \\
\hline $\begin{array}{l}\text { Inoculation with } B \text {. japonicum } 46 \\
+ \text { B. japonicum } \mathrm{KB} 11(\mathbf{1}: \mathbf{4})\end{array}$ & 46.37 & 2.05 & 18.94 & 0.35 & 13.54 \\
\hline $\begin{array}{l}\text { Inoculation with B. japonicum } 46 \\
+ \text { B. japonicum KB11 (4: 1) }\end{array}$ & 46.77 & 2.07 & 24.11 & 0.42 & 25.90 \\
\hline $\mathrm{HIP}_{05}$ & 1.96 & 0.13 & 3.32 & 0.03 & 2.62 \\
\hline
\end{tabular}

When growing soybean variety Omega Vinnytska, the same as in the experiment with soybean variety Ustia, B. japonicum 46 and B. japonicum $\mathrm{KB} 11$ in the ratio of $1: 1$ were better for the most parameters. Compared to monoinoculation, such binary composition significantly contributed to increasing the number of nodules (by 16.3-17.2\%), their weight (by $11.1 \%$ ), and nitrogenase activity (1.85-1.93 times). Plant height was increased by $10.8-11.2 \%$, and top - by $8.7-10.9 \%$.

The combination of two studied strains of rhizobia in inoculum in the ratio of $4: 1$ also had a positive effect on plant height of soybean variety Omega Vinnytska, weight of nodules, and activity of symbiotic nitrogen fixation. In this variant, a significant increase in these parameters compared to monoinoculation has been observed.

It should be noted that in both soybean varieties, inoculation with studied rhizobia both separately and as part of a binary composition, gave a significant intensification of the synthesis of chlorophyll (Table 3). For example, when growing soybean variety Ustia, in variants with different ratios of soybean rhizobia strains, content of chlorophyll $a$ and sum of chlorophyll $a$ and $b$ in the biomass of leaves were increased by $3.5-16.6 \%$ and $5.8-20.7 \%$, respectively, compared to monoinoculation. The maximum of these parameters $(180.46 \mathrm{mg} / 100 \mathrm{~g}$ and $224.51 \mathrm{mg} / 100 \mathrm{~g}$, respectively) was observed in the variant with concomitant use of the strains B. japonicum 46 and B. japonicum KB11 in the ratio of $1: 1$.

The greatest accumulation of photosynthetic pigments in biomass of the leaves of soybean of variety Omega Vinnytska was observed under the use of strains of rhizobia $B$. japonicum 46 and B. japonicum $\mathrm{KB} 11$ in the ratio of $1: 1$ and $1: 4$. In other variants reliable, but somewhat lower rise of the content of chlorophyll $a$ and sum of chlorophyll $a$ and $b$ compared with monoinoculation was obtained. Please note that 
Table 3. Content of chlorophyll in the biomass of the leaves of soybean of different varieties at the influence of inoculation with binary composition of strains B. japonicum, vegetation experiment

\begin{tabular}{|c|c|c|c|c|c|c|}
\hline \multirow{3}{*}{ Variants of experiment } & \multicolumn{6}{|c|}{ Amount of chlorophyll, mg/100 g } \\
\hline & \multicolumn{3}{|c|}{ Ustia variety } & \multicolumn{3}{|c|}{ Omega Vinnytska variety } \\
\hline & $a$ & $b$ & $a+b$ & $a$ & $b$ & $a+b$ \\
\hline Without inoculation (control) & 99.83 & 27.13 & 126.96 & 56.59 & 15.65 & 72.24 \\
\hline Inoculation with $B$. japonicum 46 & 164.97 & 47.30 & 212.27 & 93.39 & 27.13 & 120.53 \\
\hline $\begin{array}{l}\text { Inoculation with } \\
\text { B. japonicum KB11 }\end{array}$ & 154.74 & 31.24 & 185.98 & 98.00 & 29.39 & 127.39 \\
\hline $\begin{array}{l}\text { Inoculation with } B \text {. japonicum } 46 \\
+ \text { B. japonicum KB11 (1: : })\end{array}$ & 180.46 & 44.06 & 224.51 & 134.46 & 38.56 & 173.03 \\
\hline $\begin{array}{l}\text { Inoculation with } B \text {. japonicum } 46 \\
+ \text { B. japonicum } \mathrm{KB} 11(\mathbf{1}: \mathbf{2})\end{array}$ & 167.06 & 46.86 & 213.91 & 128.22 & 30.09 & 158.31 \\
\hline $\begin{array}{l}\text { Inoculation with } B \text {. japonicum } 46 \\
+ \text { B. japonicum KB11 }(\mathbf{2}: \mathbf{1})\end{array}$ & 160.14 & 50.69 & 210.84 & 111.74 & 35.67 & 147.41 \\
\hline $\begin{array}{l}\text { Inoculation with } B \text {. japonicum } 46 \\
+ \text { B. japonicum } \mathrm{KB} 11(\mathbf{1}: \mathbf{3})\end{array}$ & 163.77 & 47.61 & 211.38 & 120.19 & 35.97 & 156.16 \\
\hline $\begin{array}{l}\text { Inoculation with } B . \text { japonicum } 46 \\
+ \text { B. japonicum } \mathrm{KB} 11(\mathbf{3}: \mathbf{1})\end{array}$ & 188.70 & 33.43 & 222.12 & 114.81 & 33.79 & 148.59 \\
\hline $\begin{array}{l}\text { Inoculation with B. japonicum } 46 \\
+ \text { B. japonicum KB11 (1: : 4) }\end{array}$ & 167.29 & 52.61 & 219.90 & 128.19 & 39.55 & 167.74 \\
\hline $\begin{array}{l}\text { Inoculation with B. japonicum } 46 \\
+ \text { B. japonicum KB11 (4 : 1) }\end{array}$ & 160.55 & 42.09 & 202.64 & 116.41 & 32.54 & 148.95 \\
\hline $\mathrm{HIP}_{05}$ & 9.43 & 8.76 & 12.19 & 4.41 & 3.48 & 6.68 \\
\hline
\end{tabular}

in case of combination of two strains in inoculum in the ratio of $4: 1$, despite of the growing of symbiotic parameters, content of chlorophyll in the leaves of plants is increased only in soybean of variety Omega Vinnytska.

For better understanding of the effect of rhizobia on formation of symbiotic system, we determined the proportion of strains $B$. japonicum 46 and B. japonicum KB11 in nodules of soybean of varieties Ustia and Omega Vinnytska (Table 4).

Studies have shown that after the use of strains B. japonicum 46 and B. japonicum 46 KB11 in the ratio of $1: 1$ in both varieties of soybean, number of root nodules formed by these microorganisms was almost similar $54.2 \%: 45.8 \%$ and $45.8 \%: 54.2 \%$. It has been established that increasing the proportion of a particular strain in binary composition $(1 \rightarrow 2 \rightarrow 3 \rightarrow 4)$ provided corresponding increase of its proportion in nodules. After inoculation with B. japonicum $46+$ B. japonicum KB11 $(1: 2)$, distribution of strains in nodules was -
$25.0 \%: 75.0 \%$, whereas in case of proportion of strains $B$. japonicum 46 and $B$. japonicum KB11 (2:1) - 83.3\%: $16.7 \%$, respectively. The only exception were two variants: on soybean of variety Ustia with the use of strains B. japonicum 46 and B. japonicum $\mathrm{KB} 11$ in the ratio of $3: 1$ (their proportion in nodules was similar - 50.0\%: $50.0 \%$ ) on soybean of varieties Omega Vinnytska with a ratio of strains of $2: 1$ (their proportion amounted to $41.7 \%$ : : $58.3 \%$ ). That is, the dominance of a particular strain of rhizobia in the inoculum is not always ensured its dominance in the nodules.

It should be noted that regardless of the ration of rhizobia in binary compositions, there was no full replacement of one strain by another one from the nodule populations. Each strain occupied its ecological niche, which may indicate the presence of close mutual regulation of the amount of symbiotic nitrogen fixers in the rhizosphere of soybean, as well as their ability to compete for specific binding sites on the roots of plants. 
Table 4. Portion of strains B. japonicum 46 and B. japonicum KB11 in nodules of soybean varieties Ustia and Omega Vinnytska, vegetation experiments

\begin{tabular}{|c|c|c|c|c|}
\hline \multirow{3}{*}{ Variants of experiment } & \multicolumn{4}{|c|}{ Proportion of strains of soybean rhizobia in nodules, $\%$} \\
\hline & \multicolumn{2}{|c|}{ Ustia } & \multicolumn{2}{|c|}{ Omega Vinnytska } \\
\hline & $\begin{array}{l}\text { B. japoni- } \\
\text { cum } 46\end{array}$ & $\begin{array}{l}\text { B. japoni- } \\
\text { cum KB11 }\end{array}$ & $\begin{array}{l}\text { B. japoni- } \\
\text { cum } 46\end{array}$ & $\begin{array}{c}\text { B. japoni } \\
\text { cum KB11 }\end{array}$ \\
\hline Without inoculation (control) & 0 & 0 & 0 & 0 \\
\hline Inoculation with $B$. japonicum 46 & 100.0 & 0 & 100.0 & 0 \\
\hline $\begin{array}{l}\text { Inoculation with } B \text {. japonicum } \\
\text { KB11 }\end{array}$ & 0 & 100.0 & 0 & 100.0 \\
\hline $\begin{array}{l}\text { Inoculation with } B \text {. japonicum } 46+ \\
\text { B. japonicum KB11 (1:1) }\end{array}$ & 54.2 & 45.8 & 45.8 & 54.2 \\
\hline $\begin{array}{l}\text { Inoculation with } B \text {. japonicum } 46+ \\
\text { B. japonicum KB11 (1:2) }\end{array}$ & 25.0 & 75.0 & 33.3 & 66.7 \\
\hline $\begin{array}{l}\text { Inoculation with } B \text {. japonicum } 46+ \\
\text { B. japonicum KB11 (2:1) }\end{array}$ & 83.3 & 16.7 & 41.7 & 58.3 \\
\hline $\begin{array}{l}\text { Inoculation with } B \text {. japonicum } 46+ \\
\text { B. japonicum KB11 (1:3) }\end{array}$ & 12.5 & 87.5 & 4.2 & 95.8 \\
\hline $\begin{array}{l}\text { Inoculation with } B \text {. japonicum } 46+ \\
\text { B. japonicum KB11 (3:1) }\end{array}$ & 50.0 & 50.0 & 79.2 & 20.8 \\
\hline $\begin{array}{l}\text { Inoculation with } B \text {. japonicum } 46+ \\
\text { B. japonicum KB11 (1:4) }\end{array}$ & 12.5 & 87.5 & 8.3 & 91.7 \\
\hline $\begin{array}{l}\text { Inoculation with } B \text {. japonicum } 46+ \\
\text { B. japonicum KB11 (4:1) }\end{array}$ & 79.2 & 20.8 & 75.0 & 25.0 \\
\hline
\end{tabular}

The effectiveness of soybean inoculation with strains of B. japonicum 46 and B. japonicum KB11 and their binary composition (ratio of strains of $1: 1)$ was studied in a field experiment on the background of a small local population of specific rhizobia.

Inoculation of soybean seeds with studied strains helped to increase productivity of culture by $14.3-17.0 \%$ compared to control (Table 5). The combined use of these strains in binary composition - B. japonicum $46+$ B. japonicum KB11 was more efficient. In this variant, we received the maximum yield of soybean grain $-2.90 \mathrm{t} / \mathrm{ha}$.

Thus, the results of the conducted studies showed that the greatest effect from soybean bacterization can be obtained by a combination of two strains of rhizobia with slow (B. japonicum 46) and intensive (B.japonicum KB11) growth in the ratio of $1: 1$ (binary composition) in inoculum. Concomitant use of strains contributed to the formation of balanced symbiotic system, raising the level of fixation of molecular nitrogen, chlorophyll content in biomass of lea- ves and top of soybean of different varieties by $7.8-19.6 \%$ compared with parameters in case of monoinoculation.

Table 5. Seed productivity of soybean of variety Ustia under the effect of combined inoculation with slowly and intensely growing strains of rhizobia, field experiment, 2013

\begin{tabular}{|l|c|c|}
\hline \multicolumn{1}{|c|}{ Варіанти досліду } & $\begin{array}{c}\text { Productivity, } \\
\text { t/ha }\end{array}$ & $\begin{array}{c}\text { Yield } \\
\text { raise, } \%\end{array}$ \\
\hline $\begin{array}{l}\text { Without inoculation } \\
\text { (control) }\end{array}$ & 2.23 & - \\
\hline $\begin{array}{l}\text { Inoculation with } \\
\text { B japonicum } 46\end{array}$ & 2.61 & 17.0 \\
\hline $\begin{array}{l}\text { Inoculation with } \\
\text { B. japonicum } \text { KB11 }\end{array}$ & 2.55 & 14.3 \\
\hline $\begin{array}{l}\text { Inoculation with } \\
\text { B. japonicum } 46 \\
+ \text { B. japonicum } \text { KB11 }\end{array}$ & 2.90 & 30.0 \\
\hline HIP 05 & 0.21 & \\
\hline
\end{tabular}


Against the background of soil population of specific rhizobia, inoculation of soybean by the composition of strains B. japonicum $46+$ $B$. japonicum KB11 provided increase in productivity of culture by $11.1-13.7 \%$ compared to monoinoculation.

Further studies of binary composition of the strains $B$. japonicum are promising from a scientific and practical point of view. They allow reveal the deeper features of formation and functioning of efficient symbiotic systems under the infection of soybean by two strains both at the absence of soybean rhizobia in the soil, and at the background of the local populations of rhizobia.

1. Тихонович И. А. Значение биологической фиксации азота для современной биологии и практики сельскохозяйственного производства / И. А. Тихонович // Аграрная наука. - 1993. № 3. - C. 29-31.

2. Биологическая фиксация азота: бобоворизобиальный симбиоз : [монография : в 4-х т.] / [С. Я. Коць, В. В. Моргун, В. Ф. Патыка и др.]. - Т. 2. - К. : Логос, 2011. - 523 с.

3. Толкачев Н. 3. Потенциальные возможности симбиотической азотфиксации при выращивании сои на юге Украины / Н. 3. Толкачев // Мікробіол. журн. - 1997. - Т. 59, № 4. C. 34-41.

4. Патика В. П. Вплив аборигенних популяцій бульбочкових бактерій сої на симбіотичну активність інтродукованого штаму Bradyrhizobium japonicum 6346 / В. П. Патика, Д. В. Крутило, Т. М. Ковалевська // Мікробіол. журн. 2004. — T. 66, № 3. - C. 14-21.

\section{КОМПОЗИЦІЯ ШТАМIВ BRADYRHI- ZOBIUM JAPONICUM TA IIÏ ЗАCTOCУ- ВАННЯ ДЛЯ ІНОКУЛЯЦІї СОї}

\section{Д. В. Крутило}

Інститут сільськогосподарської мікробіології та агропромислового виробництва НААН, м. Чернігів

За умов вегетаиійних дослідів встановлено, шуо найбільший ефект від бактеризаиіі сої можна отримати при поєднанні в інокулюмі двох итамів бульбочкових бактерій 3 повільним (Bradyrhizobium japonicum 46) ma інтенсивним (B. japonicum KB11) ростом y співвідношенні 1:1 (бінарна композиція).
5. Штам бульбочкових бактерій сої $з$ підвищеною сапрофітною компетентністю як основа біопрепаратів / [Д. В. Крутило, М. А. Ушакова, С. І. Колісник та ін.] // Корми і кормовиробництво. — 2015. - Вип. 80. - С. 59-65.

6. Сытников Д. М. Биотехнология микроорганизмов-азотфиксаторов и перспективы применения препаратов на их основе / Д. М. Сытников // Біотехнологія. - 2012. - Т. 5, № 4. C. 34-45.

7. Злотников А. К. Взаимосвязь нитрогеназной активности, устойчивости и относительного содержаний компонентов смешанных культур диазотрофных бактерий / А. К. Злотников, О. Б. Глаголева, М. М. Умаров // Микробиология. - 1997. - Т. 66, № 6. - С. 807-812.

8. Masciarelli O. A new PGPR co-inoculated with Bradyrhizobium japonicum enhances soybean nodulation / O. Masciarelli, A. Llanes, V. Luna // Microbiol. Res. - 2014. - Vol. 169, № 8. P. 609-615.

9. Эффективность полиштаммовой инокуляции гороха / А. И. Чундерова, Т. И. Селиверстова, С. М. Алисова, И. Ф. Орлова // Тр. ВНИИСХМ. - Л., 1978. — Т. 47. - С. 74-83.

10. Гродзинский А. М. Краткий справочник по физиологии растений / А. М. Гродзинский, Д. М. Гродзинский. - К. : Наукова думка, 1973. -398 c.

11. Кэбот Э. Экспериментальная иммунология / Э. Кэбот, Б. Мейер. - М. : Медицина, 1968. - $677 \mathrm{c}$.

12. The acetylene-ethylene assay for $\mathrm{N}_{2}$-fixation: Laboratory and field evaluation / R. W. F. Hardy, R. D. Holsten, E. K. Jackson, R. C. Burns // Plant Physiol. - 1968. - Vol. 43, № 8. - P. 1185-1207.

\section{КОМПОЗИЦИЯ ШТАММОВ ВRADYRH- IZOBIUM JAPONICUM И ЕЁ ПРИМЕНЕ- НИЕ ДЛЯ ИНОКУЛЯЦИИ СОИ}

\section{Д. В. Крутило}

Институт сельскохозяйственной микробиологии и агропромышленного производства НААН, г. Чернигов

В условиях вегетационных опьтов показано, что наибольший эффект от бактеризачии сои можно получить при сочетании в инокулюме двух итаммов клубеньковых бактерий с медленным (Bradyrhizobium jaропісит 46) и интенсивным (B. jаропісит КВ11) ростом в соотношении 1:1 (бинар- 
Сумісне використання ичи итамів сприяло формуванню збалансованої симбіотичної системи, підвищенню рівня фіксації молекулярного азоту, вмісту хлорофілів у біомасі листя та надземної маси рослин сої різних сортів на 7,8-19,6\% відносно моноінокуляuіiі. $У$ польовому досліді інокулячія насіння сої композииією штамів В. јаропісит сприяла збільшенню урожайності сої на 11,113,7\% порівняно з моноінокуляцією.

Ключові слова: Bradyrhizobium japoniсит, бінарна композиція штамів, інокуляція, врожайність, соя. ная композиция). Совместное использование штаммов способствовало формированию сбалансированной симбиотической системbl, повышению уровня фиксачии молекулярного азота, содержания хлорофиллов в биомассе листьев и надземной массы растений сои различных сортов на 7,8-19,6\% относительно моноинокулящии. В полевом опыте инокуляция семян сои композицией штаммов В. јаропісит способствовала увеличению урожайности сои на 11,1-13,7\% по сравнению с моноинокулящией.

Ключевые слова: Bradyrhizobium japoniсит, бинарная композиция штаммов, инокуляции, урожайность, соя. 